Article

\title{
Topographical Characteristics of Agricultural Potential Productivity during Cropland Transformation in China
}

\author{
Yuejiao Li ${ }^{1,2}$, Xiaohuan Yang ${ }^{1, *}$, Hongyan Cai ${ }^{1}$, Linlin Xiao ${ }^{1,2}$, Xinliang Xu ${ }^{1}$ and Luo Liu ${ }^{1,2}$ \\ 1 State Key Laboratory of Resources and Environmental Information System, \\ Institute of Geographic Sciences and Natural Resources Research, Chinese Academy of Sciences, \\ Beijing 100101, China; E-Mails: liyuejiao@1reis.ac.cn (Y.L.); caihy@1reis.ac.cn (H.C.); \\ xiaoll.13b@igsnrr.ac.cn (L.X.); xux1@1reis.ac.cn (X.X.); liuluo87930@gmail.com (L.L.) \\ 2 University of Chinese Academy of Sciences, Beijing 100049, China \\ * Author to whom correspondence should be addressed; E-Mail: yangxh@lreis.ac.cn; \\ Tel.: +86-10-6488-8608.
}

Academic Editor: Marc A. Rosen

Received: 4 September 2014 / Accepted: 15 December 2014 / Published: 24 December 2014

\begin{abstract}
Terrain, an important limiting factor in land use change, strongly influences agricultural productivity. This study investigated the topographical characteristics of agricultural potential productivity of cropland transformations in China during the first decade of the 21 st century, and explored the impacts of cropland transformations with different terrains on agricultural potential productivity as it relates to China's national food supply. The results showed the production potential of cropland loss was much greater than that of cropland gain in most regions, and topographical characteristics of croplands losses and gains actually impacted the agricultural potential productivity in China. The losses in agricultural potential productivity was serious in regions with good terrain conditions, where the slope is lower than $5^{\circ}$, and the elevation is below $100 \mathrm{~m}$, especially in the middle and lower Yangtze region and the Huang-Huai-Hai region. The situation for cropland loss with better quality, and expanded the worse was severe in China, and this is expected to negatively influence sustainable agricultural development in the future. This study suggests that researchers focus not only on the total area of expanded cropland but also on cropland quality, such as the different terrain conditions of the croplands, to avoid a loss in national agricultural productivity caused by the process of cropland transformation.
\end{abstract}


Keywords: China; agricultural potential productivity; cropland loss; cropland gain; topographical elements

\section{Introduction}

China has nearly $20 \%$ of the global population with a much smaller than average area of cropland per capita, so maintaining China's ability to feed itself is extremely important. This prompted the government to reconsider the sustainability of China's food supply [1]. In recent years, the government used expanded croplands to compensate for croplands losses at the provincial scale. The terrain conditions obviously differ widely between cropland lost and cropland gained in China. In this paper, the word "cropland loss" is used to indicate any land removed from agricultural production. Cropland gain refers to cropland that has been occupied for other uses. The croplands gains are tracked at the province level in an attempt to guarantee a continuous supply of cropland and an adequate amount of food. The terrain differences in production potential between croplands losses and expanded croplands have led to the differences in agricultural production potential. Therefore, evaluating the differences in agricultural production potential between croplands losses and gains using terrain factors is very important [2,3].

In recent years, scientists have conducted many studies of the effect of cropland transformation on agricultural productivity [4-7]. Weinhold estimated the decrease in cropland productivity due to deforestation in Amazon area by using LUCC model and Generalized Least Square (GLS) formula [8]. Ramankutty et al. reviewed the major changes in global distribution of croplands during the 20th century, and found that the global food production system was becoming increasingly vulnerable [9]. Deng et al. examined the changes of the area of cultivated land and its potential agricultural productivity in China, and concluded that conversion of cultivated land has not hurt China's national food security between 1986 and 2000 [10]. Yang et al. discussed the effect of croplands losses and gains on potential productivity from 2000 to 2008 in China, and found that cropland loss was mainly distributed in the Huang-Huai-Hai Plain, and the middle and lower reaches of the Yangtze River with better climatic and natural conditions [11]. Wang et al. demonstrated that better croplands losses and worse croplands gains had an important effect on total light-temperature potential productivity at country level from 1990 to 2010 [12]. Cai et al. analyzed the spatiotemporal patterns of the transformation of cropland into urbanized land using data derived from Landsat TM/ETM+ images and discussed how this conversion has affected agricultural productivity [13]. Importantly, the impact of topographical characteristics of cropland transformation on agricultural potential productivity may have been ignored. Li et al. found that topographical conditions of croplands losses were much better than croplands gains in China from 2000 to 2010, but that study did not investigate how extent it impacts on agricultural potential productivity [14]. Although topographical conditions of croplands losses were much better than croplands gains, it may not impact the agricultural potential productivity.

Using topographical data, land use/land cover change data, and agricultural production potential data from 2000 to 2010, we analyzed the topographical characteristics of production potential of China's croplands losses and gains while considering slope and elevation as the main topographical parameters. Three important issues are addressed: (1) the change of production potential of croplands losses and 
gains from 2000 to 2010; (2) the relationship between agricultural production potential of croplands losses and gains and topographical factors; (3) the impacts of this cropland transformation on land resources and the security of China's food supply.

\section{Materials and Methods}

\subsection{Land Use Change Data}

Land use change data was acquired from the Data Center for Resources and Environmental Sciences, Chinese Academy of Sciences (RESDC CAS). These data were manually extracted from Landsat $\mathrm{TM} / \mathrm{ETM}+$ images and the original land use change data were at the scale of 1:100,000. The data validated through a large amount of fieldwork, and the accuracy of the land use change data exceeded 95\% [15-17]. The data contains conversions of six classes: cropland, woodland, grassland, water bodies, built-up land, and unused land. This study only focused on the conversion between cropland and other land classes, such as cropland loss to woodland, grassland, water bodies, built-up land, and unused land, and cropland gain from woodland, grassland, water bodies, built-up land, and unused land. Data, with 1-km spatial resolution from 2000 to 2010, including information such as the current land use types of cropland loss and the source of land used to gain cropland. This cropland transformation data was produced by a $1 \mathrm{~km}$ area proportion model [15].

\subsection{Slope and Elevation Data}

To derive the topographical information, the Shuttle Radar Topography Mission digital elevation model (DEM) data for all of China was collected from RESDC CAS. Then slope and elevation data were extracted with a spatial resolution of $1 \mathrm{~km}$ using GIS techniques.

Slope was divided into four levels, $0-5^{\circ}, 5-15^{\circ}, 15-25^{\circ}$, and $>25^{\circ}$, following other authors [14,18-21]. Elevation was classified into four categories $<100 \mathrm{~m}, 100-200 \mathrm{~m}, 200-800 \mathrm{~m}$, and $>800 \mathrm{~m}$.

\subsection{Agricultural Potential Productivity Simulation Method}

The GAEZ model applied in our research was developed by the Food and Agriculture Organization and the International Institute for Applied Systems Analysis over the past 30 years [22]. Five crops (wheat, maize, rice, sweet potato, and soybean) were selected to calculate their agricultural potential productivity at a spatial resolution of $1 \mathrm{~km}$ under the average climatic conditions during 1980-2010. Those five crops are characterized by the major crops in China, providing $97.7 \%$ of the total grain output of China.

\subsubsection{Delineation of Multiple Cropping Zones}

China is one of the largest countries and has the highest multiple cropping index. As in some areas, growth period may persist long enough for crops to mature at least two times in a year, single cropping system per year cannot stand for the production potential in every area. Therefore, the delineation of multiple cropping zones must be carried out before the agricultural production potential computation. There are three steps for multiple cropping zoning: (1) classifying thermal climates through effective 
accumulated temperature calculation, frozen soil zoning and temperature profiles quantifying, (2) calculating potential evapotranspiration and actual evapotranspiration, and (3) delineating the multiple cropping zones according Tables 1 and 2.

Table 1. Delineation of multiple cropping zones in the tropics.

\begin{tabular}{cccccccc}
\hline Zone & LGP & $\mathbf{L G P}_{\mathbf{t}=\mathbf{5}}$ & $\mathbf{L G P}_{\mathbf{t}=\mathbf{1 0}}$ & $\mathbf{T S}_{\mathbf{t}=\mathbf{0}}$ & $\mathbf{T S}_{\mathbf{t}=\mathbf{1 0}}$ & $\mathbf{T S}_{\mathbf{G}} \mathbf{G}_{\mathbf{t}=\mathbf{5}}$ & $\mathbf{T S}_{\mathbf{G}} \mathbf{G}_{\mathbf{t}=\mathbf{1 0}}$ \\
\hline $\mathrm{A}$ & - & - & - & - & - & - & - \\
B & $\geq 45$ & $\geq 120$ & $\geq 90$ & $\geq 1600$ & $\geq 1000$ & - & - \\
& $\geq 220$ & $\geq 220$ & - & $\geq 5500$ & & - & - \\
C & $\geq 200$ & $\geq 200$ & $\geq 120$ & $\geq 6400$ & n.a. & $\geq 3200$ & $\geq 2700$ \\
& $\geq 180$ & $\geq 200$ & - & $\geq 7200$ & & - & - \\
& $\geq 270$ & $\geq 270$ & - & $\geq 5500$ & & - & - \\
D & $\geq 240$ & $\geq 240$ & $\geq 165$ & $\geq 6400$ & n.a. & $\geq$ & $\geq$ \\
& $\geq 210$ & $\geq 240$ & - & $\geq 7200$ & & - & - \\
E & n.a. & n.a. & n.a. & n.a. & n.a. & n.a. & n.a. \\
F & $\geq 300$ & $\geq 300$ & $\geq 240$ & $\geq 7200$ & $\geq 7000$ & $\geq 5100$ & $\geq 4800$ \\
G & n.a. & n.a. & n.a. & n.a. & n.a. & n.a. & n.a. \\
H & $\geq 360$ & $\geq 360$ & $\geq 360$ & $\geq 7200$ & $\geq 7000$ & - & - \\
\hline
\end{tabular}

Table 2. Delineation of multiple cropping zones in non-tropics zones.

\begin{tabular}{cccccccc}
\hline Zone & $\mathbf{L G P}$ & $\mathbf{L G P}_{\mathbf{t}=\mathbf{5}}$ & $\mathbf{L G P}_{\mathbf{t}=\mathbf{1 0}}$ & $\mathbf{T S}_{\mathbf{t}=\mathbf{0}}$ & $\mathbf{T S}_{\mathbf{t}=\mathbf{1 0}}$ & $\mathbf{T S}_{\mathbf{G}} \mathbf{G}_{\mathbf{t}=\mathbf{5}}$ & $\mathbf{T S}_{\mathbf{G}} \mathbf{G}_{\mathbf{t}=\mathbf{1 0}}$ \\
\hline $\mathrm{A}$ & - & - & - & - & - & - & - \\
B & $\geq 45$ & $\geq 120$ & $\geq 90$ & $\geq 1600$ & $\geq 1000$ & - & - \\
C & $\geq 180$ & $\geq 200$ & $\geq 120$ & $\geq 3600$ & $\geq 3000$ & $\geq 3200$ & $\geq 2900$ \\
D & $\geq 210$ & $\geq 240$ & $\geq 165$ & $\geq 4500$ & $\geq 3600$ & $\geq 4000$ & $\geq 3200$ \\
E & $\geq 240$ & $\geq 270$ & $\geq 180$ & $\geq 4800$ & $\geq 4500$ & $\geq 4300$ & $\geq 4000$ \\
F & $\geq 300$ & $\geq 300$ & $\geq 240$ & $\geq 5400$ & $\geq 5100$ & $\geq 5100$ & $\geq 4800$ \\
G & $\geq 330$ & $\geq 330$ & $\geq 270$ & $\geq 5700$ & $\geq 5500$ & - & - \\
H & $\geq 360$ & $\geq 360$ & $\geq 330$ & $\geq 7200$ & $\geq 7000$ & - & - \\
\hline
\end{tabular}

A can't grow plant, B single cropping per year, C triple cropping for two years, D double cropping per year (can't both be rice), E double cropping per year, F triple cropping per year (can't all be rice), G triple cropping per year (rice can't mature more than twice), $\mathrm{H}$ triple cropping per year, LGP growth period under rain-fed scenario, $\mathrm{LGP}_{\mathrm{t}=5}$ growth period above $5^{\circ}, \mathrm{LGP}_{\mathrm{t}=10}$ growth period above $10^{\circ}, \mathrm{TS}_{\mathrm{t}=0}$, effective accumulated temperature above $0^{\circ}, \mathrm{TS}_{\mathrm{t}}=10$, effective accumulated temperature above $10^{\circ}, \mathrm{TS}_{-} \mathrm{G}_{\mathrm{t}}=5$, growth period effective accumulated temperature above $5^{\circ}, \mathrm{TS}_{-} \mathrm{G}_{\mathrm{t}}=10$ growth period effective accumulated temperature above $10^{\circ}$.

\subsubsection{Calculation of Agricultural Potential Productivity}

As for the GAEZ model, agricultural potential productivity is mainly determined by the solar radiation and the seasonal temperature, while additional limitations imposed by water availability, soil characteristics, and terrain slopes determine the actual yields that are obtained under rain-fed conditions. A stepwise limiting method was used to compute agricultural potential productivity following this order: the light production potential (only limiting light), light and temperature production potential (limiting light and temperature), climatic production potential (limiting light, temperature, and water), the land 
production potential (limiting light, temperature, water, and soil), and the agricultural production potential (e.g., limiting agricultural input level, management methods) [23].

To reveal the impact of water conditons, irrigated and rain-fed scenarios were considered. Calculaton of agricultural potential productivity for the rain-fed scenarios were based on light, temperature, and water condtions, while the irrigated scenarios used only the light and temperature conditions assuming no water stress. We considered irrigated conditions to be appropriate for rice because most rice crops are cultivated under irrigation. For other crops, we considered both irrigated and rain-fed conditions. The equation used to calculated crop yields within each grid cell under rain-fed and irrigated scenarios was [24]

$$
\text { yield }_{\text {total }}=\text { yield }_{\text {rain }- \text { fed }} \times(1-i)+\text { yield }_{\text {irrigated }} \times i
$$

where yield total $_{\text {is }}$ the production potential within each grid cell $(\mathrm{kg} / \mathrm{ha})$, yieldrain - fed is the yield under rain-fed scenarios within each grid cell $(\mathrm{kg} / \mathrm{ha})$, yieldirrigated is the yield under irrigated scenarios within each grid cell $(\mathrm{kg} / \mathrm{ha})$, and $i(\%)$ is the ratio of irrigation-cultivated area to total cultivated area based on official statistics from the National Bureau of Statistics of China.

The calculated production potential in 2010 was compared with the actual production in official statistics for 2010. The cross-correlation coefficient between the calculated production potential and the actual production was 0.82 and the standard deviation was 7400 tons, indicating a good correlation. The regional statistics of GIS spatial analysis methods were used to calculate the total tones of production potential in a region. The average production potential per unit area of cropland loss and gain in a region $\left(\mathrm{t} / \mathrm{km}^{2}\right)$ was also calculated, this index can reflect the average quality of cropland loss and gain in that region.

\subsection{Agricultural Zones}

The agricultural zone data this study used was comprehensive agricultural regionalization of China made by Committee of Chinese Agricultural Regionalization in 1978. The data divided China into nine zones: Northeast region, Inner Mongolia and along the Great Wall region, Huang-Huai-Hai region, Loess plateau region, Middle and lower Yangtze region, Southwest region, Gansu-Xinjiang region, Qinghai-Tibet region and South China region (Figure 1). The natural conditions, socio-economic conditions, and agricultural production conditions were relatively consistent in each region. Northeast region is an important base of agricultural production in China with large areas of plain and fertile land. Inner Mongolia and along the Great Wall region is a major pastoral area with lots of grasslands, land desertification is serious in this region. Huang-Huai-Hai region has the largest plain areas and population density in China. Loess plateau region is the largest loess area in the world, soil and water loss and degradation of ecological environment was serious in the past years. Middle and lower Yangtze region has favorable conditions for agriculture, utilization of cropland is high in this area. The level of comprehensive development of Middle and lower Yangtze region is the highest in China, with the most population in the region. The southwest region is characterized by large areas of mountains; the quality of cropland in this area is generally poor. Solar radiation energy of Gansu-Xinjiang region is abundant, and rainfall is very little in this area. Qinghai-Tibet region is characterized by plateau, has the largest land areas and the least population, grassland is the main land resources in this region. South China 
region is distributed in subtropical and tropical areas, where water and heat conditions are very well for agriculture.

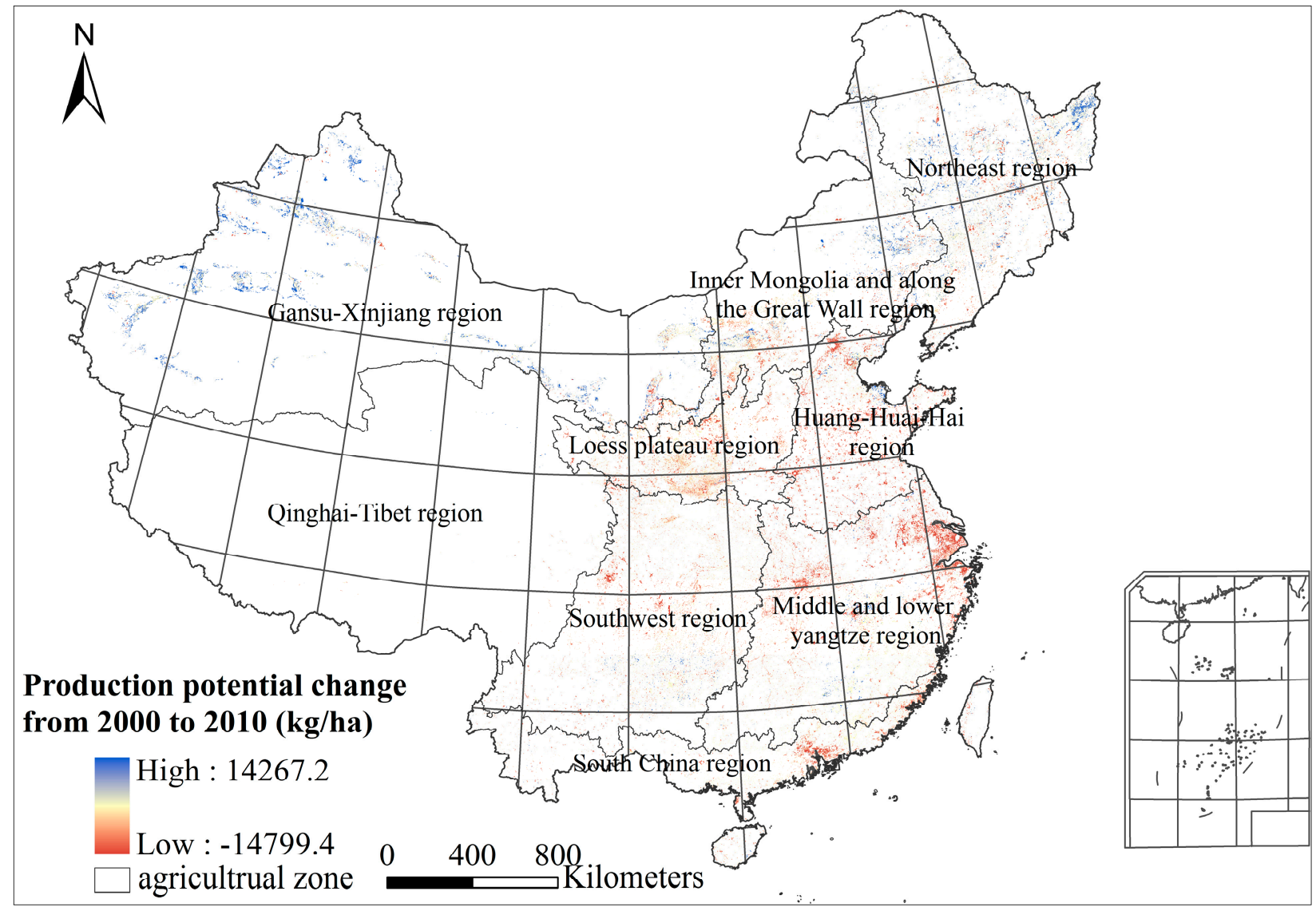

Figure 1. Production potential change of cropland in China from 2000 to 2010.

\section{Results}

\subsection{Temporal and Spatial Distribution of Production Potential of Cropland Loss and Gain}

From 2000 to 2010, the loss of production potential in China caused by the cropland loss was estimated to be $2401.98 \times 10^{4} \mathrm{t}$, and the increase of production potential caused by cropland gain was $1087.12 \times 10^{4} \mathrm{t}$, which accounted for about $45.26 \%$ of that of cropland loss. The net loss in productivity in China caused by the cropland change was $1314.88 \times 10^{4} \mathrm{t}$.

The greatest loss of production potential caused by cropland loss was observed in the middle and lower Yangtze region, and the greatest increase of production potential caused by the cropland gain was observed in the Gansu Xinjiang region (Table 3). In the northeast region and Gansu Xinjiang region, the change of production potential caused by the cropland gain was more than that caused by the cropland loss, and the net production potential increase in these two regions was $609.29 \times 10^{4} \mathrm{t}$. In the other seven regions, a net loss of production potential was observed; the greatest net loss was $823.66 \times 10^{4} \mathrm{t}$ in the middle and lower Yangtze region. 
Table 3. Production potential change of cropland loss and gain in China from 2000 to 2010 $\left(\times 10^{4} \mathrm{t}\right)$.

\begin{tabular}{lccc}
\hline \multicolumn{1}{c}{ Region } & Production Potential Loss & Production Potential Gain & Net Change \\
\hline Northeast region & 165.54 & 251.93 & 86.39 \\
Inner Mongolia and along the & 126.78 & 102.76 & -24.03 \\
Great Wall region & 561.27 & 38.49 & -522.78 \\
Huang-Huai-Hai region & 191.15 & 6.70 & -184.45 \\
Loess plateau region & 878.90 & 55.24 & -823.66 \\
Middle and lower Yangtze region & 215.38 & 23.98 & -191.40 \\
Southwest region & 74.28 & 597.19 & 522.90 \\
Gansu-Xinjiang region & 4.78 & 2.48 & -2.30 \\
Qinghai-Tibet region & 183.90 & 8.35 & -175.55 \\
South China region & & & \\
\hline
\end{tabular}

\subsection{The Relationship between Slope and Production Potential of Cropland Loss and Gain}

The optimal slope for agricultural cultivation was $0-5^{\circ}$, so this amount of slope was important in the assessment of the agricultural production potential of cropland.

At slopes of $0-5^{\circ}$, the loss of production potential caused by the cropland loss was $1989.68 \times 10^{4} \mathrm{t}$, and the increase of production potential caused by the cropland gain was $994.91 \times 10^{4} \mathrm{t}$, which accounts for about half of the loss of occupied cropland. The net loss of production potential caused by cropland transformation on slopes of $0-5^{\circ}$ was $994.77 \times 10^{4} \mathrm{t}$ (Table 4$)$.

Table 4. Change in production potential associated with the slopes of cropland loss and gain in China from 2000 to $2010\left(\times 10^{4} \mathrm{t}\right)$.

\begin{tabular}{|c|c|c|c|c|c|c|c|c|}
\hline \multirow[b]{2}{*}{ Region } & \multicolumn{4}{|c|}{ Cropland Loss } & \multicolumn{4}{|c|}{ Cropland Gain } \\
\hline & $0-5^{\circ}$ & $5-15^{\circ}$ & $15-25^{\circ}$ & $\begin{array}{c}\text { above } \\
25^{\circ}\end{array}$ & $0-5^{\circ}$ & $5-15^{\circ}$ & $15-25^{\circ}$ & $\begin{array}{c}\text { above } \\
25^{\circ}\end{array}$ \\
\hline Northeast region & 122.58 & 40.35 & 2.57 & 0.00 & 219.86 & 30.30 & 1.75 & 0.00 \\
\hline $\begin{array}{l}\text { Inner Mongolia and along the } \\
\text { Great Wall region }\end{array}$ & 86.16 & 38.92 & 1.67 & 0.00 & 90.80 & 11.61 & 0.35 & 0.00 \\
\hline Huang-Huai-Hai region & 548.89 & 10.97 & 1.31 & 0.00 & 38.21 & 0.28 & 0.00 & 0.00 \\
\hline Loess plateau region & 90.23 & 55.66 & 43.52 & 4.35 & 5.52 & 0.89 & 0.29 & 0.00 \\
\hline Middle and lower Yangtze region & 818.79 & 48.01 & 11.38 & 1.14 & 37.59 & 12.48 & 4.84 & 0.32 \\
\hline Southwest region & 90.38 & 61.03 & 52.29 & 5.23 & 3.57 & 14.85 & 5.28 & 0.27 \\
\hline Gansu-Xinjiang region & 71.31 & 2.78 & 0.19 & 0.00 & 591.86 & 5.16 & 0.17 & 0.00 \\
\hline Qinghai-Tibet region & 0.57 & 0.63 & 2.02 & 0.20 & 2.20 & 0.21 & 0.06 & 0.01 \\
\hline South China region & 160.77 & 17.57 & 4.98 & 0.50 & 5.30 & 2.07 & 0.86 & 0.12 \\
\hline
\end{tabular}

A net increase of production potential was found on slopes of $0-5^{\circ}$ in the northeast region, Inner Mongolia and along the Great Wall region, Gansu Xinjiang region, and Qinghai Tibet region. For the other regions, the loss of production potential caused by the cropland loss was more than the increase of production potential caused by the reclamation of cropland. The net loss in production potential caused by cropland conversion on $0-5^{\circ}$ slopes was more than $780 \times 10^{4} \mathrm{t}$ in the Middle and lower Yangtze region, and $510.68 \times 10^{4} \mathrm{t}$ in the Huang Huai Hai region. 
On other slopes, the loss of production potential caused by the cropland loss was more than increase in production potential created by cropland reclamation, except on the slopes of $5-15^{\circ}$ in the Gansu Xinjiang region. The net loss in production potential on other slopes was less than net loss of production potential on the $0-5^{\circ}$ slopes. Net losses in production potential on the slopes of $5-15^{\circ}, 15-25^{\circ}$, and above $25^{\circ}$ were $198.07 \times 10^{4} \mathrm{t}, 106.33 \times 10^{4} \mathrm{t}, 10.70 \times 10^{4} \mathrm{t}$, respectively.

As a result, the loss of production potential caused by cropland loss was much more than increase in production potential of cropland gain, and the net change was negatively correlated with slope; the steeper the slope, the smaller the net change. This showed that the loss of good quality cropland would lead to a significant loss of production potential.

The average production potential per $\mathrm{km}^{2}$ of cropland loss was more than that of cropland gain on the each level of slope (Table 5). The greatest difference per $\mathrm{km}^{2}$ between cropland loss and cropland gain was $550.15 \mathrm{t}$ on $0-5^{\circ}$ slopes; the second largest difference per $\mathrm{km}^{2}$ was $277.33 \mathrm{t}$ on $15-25^{\circ}$ slopes. The differences on $5-15^{\circ}$ slopes and greater than $25^{\circ}$ were relative smaller, or $220.01 \mathrm{t}$ and $79.59 \mathrm{t}$, respectively.

In Gansu-Xinjiang region, the average production potential per $\mathrm{km}^{2}$ of cropland loss was less than that of cropland gain on $0-5^{\circ}, 5-15^{\circ}$ and $15-25^{\circ}$ slopes. In South China region, the average production potential per $\mathrm{km}^{2}$ of cropland loss was less than that of cropland gain on $0-5^{\circ}, 5-15^{\circ}$ and $>25^{\circ}$ slopes, and the value of cropland loss was more than that of cropland gain on $15-25^{\circ}$ slopes. In the other seven regions, the average production potential per $\mathrm{km}^{2}$ of cropland loss was more than that of cropland gain on $0-5^{\circ}, 5-15^{\circ}$ and $15-25^{\circ}$ slopes. The biggest values of average production potential per $\mathrm{km}^{2}$ of cropland loss was $1819.34 \mathrm{t}$ in the Middle and lower Yangtze region, and 1781.14 $\mathrm{t}$ in the Huang-Huai-Hai region. The greatest differences in average production potential per $\mathrm{km}^{2}$ between cropland loss and gain was also in these two regions on slopes 5-15 : $1076.08 \mathrm{t}$ in the Huang-Huai-Hai region and $1036.35 \mathrm{t}$ in the Middle and lower Yangtze region.

Table 5. Average production potential per unit area associated with the slope of cropland loss and gain in China from 2000 to $2010\left(\mathrm{t} \cdot \mathrm{km}^{-2}\right)$.

\begin{tabular}{|c|c|c|c|c|c|c|c|c|}
\hline \multirow[b]{2}{*}{ Region } & \multicolumn{4}{|c|}{ Cropland Loss } & \multicolumn{4}{|c|}{ Cropland Gain } \\
\hline & $0-5^{\circ}$ & $5-15^{\circ}$ & $15-25^{\circ}$ & $\begin{array}{c}\text { above } \\
25^{\circ}\end{array}$ & $0-5^{\circ}$ & $5-15^{\circ}$ & $15-25^{\circ}$ & $\begin{array}{c}\text { above } \\
25^{\circ}\end{array}$ \\
\hline Northeast region & 1198.17 & 1153.24 & 1282.14 & - & 1003.47 & 761.65 & 721.74 & - \\
\hline $\begin{array}{l}\text { Inner Mongolia and along the } \\
\text { Great Wall region }\end{array}$ & 473.28 & 605.20 & 601.70 & - & 460.99 & 453.47 & 588.63 & - \\
\hline Huang-Huai-Hai region & 1781.14 & 1365.02 & 1154.23 & - & 705.06 & 1243.21 & - & - \\
\hline Loess plateau region & 1452.35 & 817.76 & 721.48 & 1436.22 & 416.00 & 406.15 & 232.83 & - \\
\hline Middle and lower Yangtze region & 1819.34 & 1545.52 & 990.31 & 880.30 & 1271.71 & 1212.97 & 742.16 & 348.97 \\
\hline Southwest region & 1549.34 & 983.11 & 666.75 & 155.07 & 1143.92 & 681.72 & 272.38 & 76.52 \\
\hline Gansu-Xinjiang region & 879.57 & 642.85 & 692.65 & - & 941.37 & 909.31 & 717.89 & - \\
\hline Qinghai-Tibet region & 295.15 & 319.16 & 396.27 & 19.54 & 261.82 & 203.64 & 172.70 & 38.42 \\
\hline South China region & 970.90 & 914.65 & 408.75 & 174.89 & 1200.01 & 1152.32 & 396.67 & 292.73 \\
\hline Total & 1409.50 & 938.35 & 690.41 & 222.69 & 859.35 & 718.34 & 413.08 & 143.10 \\
\hline
\end{tabular}




\subsection{The Relationship between Elevation and Production Potential of Cropland Loss and Gain}

The loss of production potential caused by the cropland loss below elevations of $100 \mathrm{~m}$ was $1472.39 \times 10^{4} \mathrm{t}$, which was significantly greater than that at other elevations (Table 6 ). The increase in production potential caused by the cropland gain below elevations of $100 \mathrm{~m}$ was only $166.41 \times 10^{4} \mathrm{t}$. The loss of production potential at low elevations caused by cropland loss was about $784.75 \times 10^{4} \mathrm{t}$ in the Middle and lower Yangtze region and $498.1 \times 10^{4} \mathrm{t}$ in the Huang Huai Hai region, accounting for $32.84 \%, 20.85 \%$ of the total productivity loss, respectively, while the gain of production potential was only $73.42 \times 10^{4} \mathrm{t}$ in these two regions. That is, most of the loss of production potential in China was in favorable terrain conditions at elevations $<100 \mathrm{~m}$, while cropland was rarely gain at this range of elevation.

Table 6. Production potential change associated with the elevation of cropland loss and gain in China from 2000 to $2010\left(\times 10^{4} \mathrm{t}\right)$.

\begin{tabular}{|c|c|c|c|c|c|c|c|c|}
\hline \multirow[b]{2}{*}{ Region } & \multicolumn{4}{|c|}{ Cropland Loss } & \multicolumn{4}{|c|}{ Cropland Gain } \\
\hline & $<100 \mathrm{~m}$ & $\begin{array}{c}100-200 \\
\mathrm{~m}\end{array}$ & $\begin{array}{c}200-800 \\
\mathrm{~m}\end{array}$ & $>800 \mathrm{~m}$ & $<100 \mathrm{~m}$ & $\begin{array}{c}100-200 \\
\mathrm{~m}\end{array}$ & $\begin{array}{c}200-800 \\
\mathrm{~m}\end{array}$ & $>800 \mathrm{~m}$ \\
\hline Northeast region & 35.68 & 45.24 & 84.10 & 0.44 & 85.15 & 97.19 & 67.91 & 1.76 \\
\hline $\begin{array}{l}\text { Inner Mongolia and along } \\
\text { the Great Wall region }\end{array}$ & 0.11 & 7.75 & 26.25 & 92.79 & 0.02 & 11.60 & 46.23 & 44.85 \\
\hline Huang-Huai-Hai region & 498.10 & 54.61 & 8.18 & 0.00 & 37.64 & 0.62 & 0.09 & 0.00 \\
\hline Loess plateau region & 0.00 & 7.17 & 72.52 & 111.41 & 0.00 & 0.20 & 4.32 & 2.18 \\
\hline $\begin{array}{l}\text { Middle and lower } \\
\text { Yangtze region }\end{array}$ & 784.75 & 61.61 & 31.00 & 1.17 & 35.78 & 5.61 & 13.48 & 0.39 \\
\hline Southwest region & 1.57 & 7.41 & 121.46 & 84.87 & 0.04 & 0.08 & 6.46 & 17.39 \\
\hline Gansu-Xinjiang region & 0.23 & 0.00 & 8.75 & 65.16 & 2.97 & 0.18 & 216.79 & 377.20 \\
\hline Qinghai-Tibet region & 0.00 & 0.00 & 0.01 & 4.74 & 0.00 & 0.00 & 0.00 & 2.48 \\
\hline South China region & 151.95 & 8.82 & 3.33 & 8.11 & 4.81 & 0.53 & 0.50 & 0.81 \\
\hline
\end{tabular}

Compared with elevations below $100 \mathrm{~m}$, the loss of production potential was lower at elevations of 100-200 m. A loss of only $192.61 \times 104 \mathrm{t}$ in production potential was observed in lost cropland and was mainly distributed in the Middle and lower Yangtze region and Huang Huai Hai region, and the increase in production potential of cropland gain was less than production potential loss in this level of elevation. In the 200-800 $\mathrm{m}$ elevation range, the loss and gain of production potential was nearly equal, about $355 \times 104 \mathrm{t}$. The loss of production potential caused by cropland loss at elevations $>800 \mathrm{~m}$ was more than that at elevations of 100-200 m, 200-800 m, but less than that at elevations $<100 \mathrm{~m}$. The increase in production potential caused by cropland gain at elevations $>800 \mathrm{~m}$ was more than that at the other elevations. About $377.2 \times 104 \mathrm{t}$ of production potential had been gained in the Gansu Xinjiang region, accounting for $34.76 \%$ of the total increase in production potential in China.

The average production potential per $\mathrm{km}^{2}$ of cropland loss was more than that of cropland gain at the elevations of $<100 \mathrm{~m}, 100-200 \mathrm{~m}$ and 200-800 $\mathrm{m}$ (Table 7). The differences per $\mathrm{km}^{2}$ between cropland loss and cropland gain at elevations $<100 \mathrm{~m}$ and 100-200 m were both nearly $517 \mathrm{t}$. The difference at elevations of $200-800 \mathrm{~m}$ was $397.36 \mathrm{t}$. The average production potential per $\mathrm{km}^{2}$ of cropland loss was 
less than that of cropland gain at the elevations of $>800 \mathrm{~m}$, and the difference per $\mathrm{km}^{2}$ between cropland loss and cropland gain was $143.16 \mathrm{t}$.

In the Inner Mongolia and along the Great Wall region, Huang-Huai-Hai region, Loess plateau region, Middle and lower Yangtze region, Southwest region and Qinghai-Tibet region, the average production potential per $\mathrm{km}^{2}$ of cropland loss was more than that of cropland gain at all four elevations. The biggest values of average production potential per $\mathrm{km}^{2}$ of cropland loss was $1805.98 \mathrm{t}$ in the Middle and lower Yangtze region, and $1775.99 \mathrm{t}$ in the Huang-Huai-Hai region at elevations $<100 \mathrm{~m}$. The greatest differences in average production potential per $\mathrm{km}^{2}$ between cropland loss and gain was $1603.05 \mathrm{t}$ in the Gansu-Xinjiang region at elevations $<100 \mathrm{~m}$.

Table 7. Average production potential per unit area associated with the elevation of cropland loss and gain in China from 2000 to $2010\left(\mathrm{t} \cdot \mathrm{km}^{-2}\right)$.

\begin{tabular}{|c|c|c|c|c|c|c|c|c|}
\hline \multirow[b]{2}{*}{ Region } & \multicolumn{4}{|c|}{ Cropland Loss } & \multicolumn{4}{|c|}{ Cropland Gain } \\
\hline & $<100 \mathrm{~m}$ & $\begin{array}{c}100-200 \\
\mathrm{~m}\end{array}$ & $\begin{array}{c}200-800 \\
\mathrm{~m}\end{array}$ & $\begin{array}{c}>800 \\
\mathrm{~m}\end{array}$ & $<100 \mathrm{~m}$ & $\begin{array}{c}100-200 \\
\mathrm{~m}\end{array}$ & $\begin{array}{c}200-800 \\
\mathrm{~m}\end{array}$ & $\begin{array}{c}>800 \\
\mathrm{~m}\end{array}$ \\
\hline Northeast region & 1289.80 & 1199.43 & 1155.38 & 352.95 & 1451.88 & 931.36 & 704.35 & 918.13 \\
\hline $\begin{array}{l}\text { Inner Mongolia and along the } \\
\text { Great Wall region }\end{array}$ & 1182.24 & 576.69 & 635.22 & 476.68 & 442.92 & 479.62 & 482.75 & 434.99 \\
\hline Huang-Huai-Hai region & 1775.99 & 1769.82 & 1499.89 & - & 709.74 & 575.99 & 1393.78 & - \\
\hline Loess plateau region & - & 1387.96 & 1652.46 & 771.48 & - & 585.73 & 442.60 & 328.08 \\
\hline Middle and lower Yangtze region & 1805.98 & 1720.45 & 1332.51 & 817.41 & 1198.14 & 1283.36 & 1000.45 & 489.50 \\
\hline Southwest region & 1311.03 & 795.43 & 1254.30 & 677.80 & 443.70 & 365.09 & 365.92 & 583.07 \\
\hline Gansu-Xinjiang region & 2215.71 & - & 854.14 & 868.16 & 612.66 & 504.76 & 1023.06 & 903.50 \\
\hline Qinghai-Tibet region & - & - & 1379.78 & 248.14 & - & - & - & 246.97 \\
\hline South China region & 935.65 & 1128.36 & 922.24 & 499.41 & 1281.99 & 985.50 & 767.39 & 392.08 \\
\hline Total & 1624.34 & 1374.47 & 1195.63 & 638.57 & 1107.34 & 856.53 & 798.27 & 781.73 \\
\hline
\end{tabular}

\section{Discussion}

In steep slope areas, soils had low fertility and poor water holding capacity, road density was small, transportation costs of food were high, and farmers had relatively lower agricultural input, which may cause agricultural productivity to decline as slope increases. Additionally, in high elevation areas, transportation costs of food were high, little human activity, and farming in these areas required higher labor costs. As a result, agricultural productivity was low in high elevation areas.

Previous researchers have documented the presence of some relationships between agricultural productivity and terrain conditions. Zhou proved that agricultural output of per unit area declined with an increase in elevation, and a similar relationship existed between slope and cropland in the Three Gorges Reservoir area [18]. Wei et al. found that high quality cropland distributed in the areas below $400 \mathrm{~m}$ and on slopes less than $15^{\circ}$ in Wengyuan County, Guangdong Province [19]. Li et al. documented a significant negative correlation between slope gradient and energy input-output ratios in Wugou Village, Henan province [25]. The Three Gorges Reservoir area was in the Southwest region. Wengyuan County was in the Middle and lower Yangtze region. Wugou Village was in the Loess plateau region. Those results support our results, showing that terrain affects agricultural productivity. As noted above, 
optimal terrain conditions for agricultural cultivation were found on $0-5^{\circ}$ slopes and at low elevations. Steeper slopes or higher elevations will limit agricultural productivity. In China, we found croplands losses had a higher value of average productivity per unit area in areas with lower slope and elevation. Meanwhile, we found croplands gains with a lower average productivity per unit area in areas with higher slopes and elevations. Most croplands losses were in areas with greater agriculture potential productivity, and croplands gains tended to be created in areas with lower agriculture potential productivity during the first decade of the 21 st century.

The losses of agricultural potential productivity were serious in the middle and lower Yangtze region $\left(878.90 \times 10^{4} \mathrm{t}\right)$ and the Huang-Huai-Hai region $\left(561.27 \times 10^{4} \mathrm{t}\right)$. In the middle and lower Yangtze, $690.69 \times 10^{4} \mathrm{t}$ losses of agricultural potential productivity due to urbanization, the losses were $484.90 \times 10^{4} \mathrm{t}$ in the Huang-Huai-Hai region, accounting for $78.59 \%$ and $86.39 \%$ of the total losses of agricultural potential productivity in the region, respectively. These two regions have large plain areas and favorable conditions for agriculture. Terrain conditions of cropland losses in these two regions were quite good. In the middle and lower Yangtze and Huang-Huai-Hai region, the losses of agricultural potential productivity due to urbanization were $651.21 \times 10^{4} \mathrm{t}, 475.89 \times 10^{4} \mathrm{t}$ on the slopes of $0-5^{\circ}$, and $626.13 \times 10^{4} \mathrm{t}, 440.42 \times 10^{4} \mathrm{t}$ at the elevations $<100 \mathrm{~m}$, respectively.

Northeast region is an important base of agricultural production in China with large areas of plain and fertile land. The gains of production potential was $251.93 \times 10^{4} \mathrm{t}$ in this area. Production potential gains were mainly from woodland $85.98 \times 10^{4} \mathrm{t}(34.13 \%)$, unused land $85.04 \times 10^{4} \mathrm{t}(33.76 \%)$ and grassland $75.06 \times 10^{4} \mathrm{t}(29.79 \%) .69 .96 \%$ of production potential from woodland was on the slopes of $0-5^{\circ}$, and $32.1 \%$ at the elevations $<100 \mathrm{~m} .99 .18 \%$ of production potential from unused land was on the slopes of $0-5^{\circ}$, and $50.13 \%$ at the elevations $<100 \mathrm{~m}$. $69.08 \%$ of production potential from grassland was on the slopes of $0-5^{\circ}$, and $50.04 \%$ at the elevations $100-200 \mathrm{~m}$. Terrain conditions of croplands gains in this region was very well, that made contributions to the sustainability of China's food supply. In the Gansu-Xinjiang region, the gains of production potential was $597.19 \times 10^{4} \mathrm{t}$, that was mainly from grassland (60.86\%). Solar radiation energy of Gansu-Xinjiang region is abundant, and rainfall is very little in this area. Limited by water resources, the production potential maybe increased the most in China, but the actual agricultural production may not increase so much. This area mainly planted economic crops, such as cotton and sugar, because the cost of transport grain crops to other regions was high.

Based on data from the 2011 China Statistical Yearbook, nearly $70 \%$ of all food production was in the major grain-producing areas in China, including Anhui, Hebei, Heilongjiang, Henan, Hunan, Jiangsu, Jiangxi, Jilin, Shandong, and Sichuan. Most of these provinces were in the Huang-Huai-Hai region, Middle and lower Yangtze region and Northeast region, while the results showed that the net loss of production potential was $1346.44 \times 10^{4} \mathrm{t}$ in the Huang-Huai-Hai region and Middle and lower Yangtze region, accounting for $2.17 \%$ of the entire production potential in these two regions in 2000.

Over the past decade, as technology advanced, the use of chemical fertilizers and pesticides has increased, cropland management improved, and efficiency in farming has been greatly improved. However, the food production decreased in 11 provinces, covering nearly $35.5 \%$ of all provinces of China (Figure 2). One of the possible reasons for the decrease in agricultural production was that provinces with croplands losses could produce more food, while croplands gains could produce less food. If China continues to lose high quality cropland, food production will inevitably decline in the near 
future. Therefore, efforts to cropland gain should focus not only on total area but also on the quality of agricultural potential production in different types of terrain.

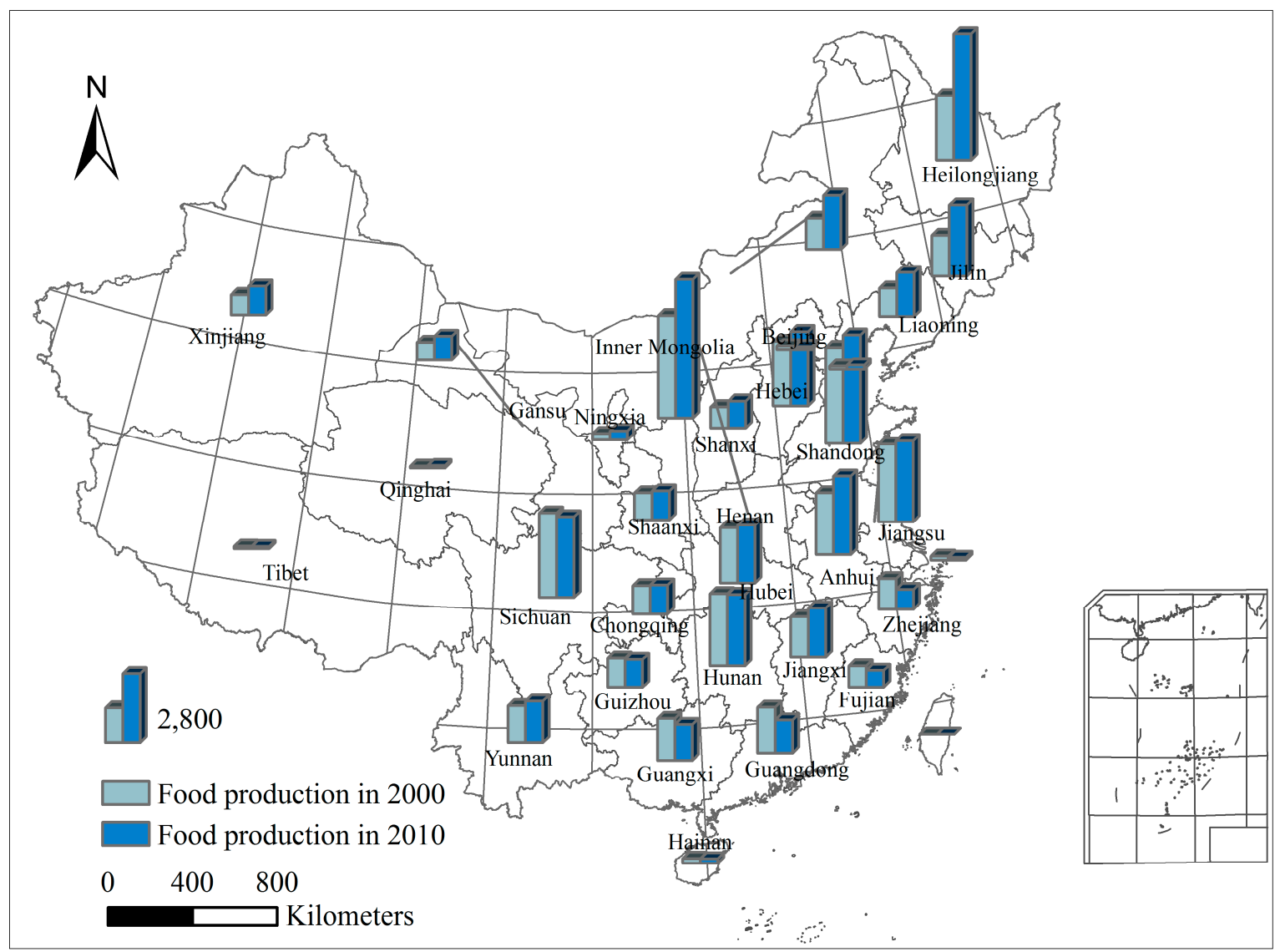

Figure 2. Food production in China's provinces in 2000 and 2010.

\section{Conclusions}

The techniques used in this study calculated the agricultural potential productivity of China in 2000 and 2010, and analyzed the impact of topographical characteristics of croplands losses and gains on agricultural potential productivity in nine agricultural zones from 2000 to 2010 . Our results may provide valuable insights that could help improve China's land use policies to meet national and regional food security.

The results showed: (1) From 2000 to 2010, the net loss of production potential in China caused by the cropland transformation was $1314.88 \times 10^{4} \mathrm{t}$, which account for $1.05 \%$ of the total production potential in 2000 . The production potential of cropland loss was much greater than that of cropland gain in most regions. The greatest loss of production potential caused by cropland loss was in the middle and lower Yangtze region $\left(878.90 \times 10^{4} \mathrm{t}\right)$ and the Huang-Huai-Hai region $\left(561.27 \times 10^{4} \mathrm{t}\right)$; (2) Topographical characteristics of croplands losses and gains actually impacted the agricultural potential productivity in China, the losses of agricultural potential productivity were serious in regions with good terrain conditions, where the slope was lower than $5^{\circ}$ and the elevation was below $100 \mathrm{~m}$, especially in the middle and lower Yangtze region and the Huang-Huai-Hai region. During the first decade of the 21st century, during the process of cropland transformation policy implementation, a large number of 
high-quality cropland resources were lost. Simultaneously, the terrain conditions of expanded cropland were poor. This combination is expected to negatively affect the stability of China's food supply.

China's current national land use policy calls for the replacement of croplands losses with expanded croplands by tracking land use at the provincial level. Based on our analysis, this selection of expanded cropland areas should focus not only on the total area involved but also on the quality of the expanded land, such as the different terrain conditions of the croplands. The conditions of the expanded cropland should be investigated and assessed. This should include a periodic census of the area and an assessment of changes in agricultural productivity of both croplands losses and gains, to make sure that the replacement of croplands losses with expanded land will not result in a loss in national agricultural productivity during the process of cropland transformation. Simultaneously, when policy makers make the planning to control of the use of a land, should also consider the terrain conditions of cropland, to ensure the agricultural productivity.

\section{Acknowledgments}

This research was jointly supported by the National Research Programs (2012BAI32B06, 2012BAI32B07), the Project of the National Natural Science Foundation of China (41271173, 41301155) and a special project of the Ministry of Science and Technology (2012FY111800-01-01). We would like to thank the editor and all the reviewers for their helpful suggestions and comments on this paper.

\section{Author Contributions}

Yuejiao Li analyzed the data and wrote the paper; Xiaohuan Yang, Hongyan Cai and Linlin Xiao modified the paper, Xinliang Xu and Luo Liu made contribution to agricultural potential productivity data.

\section{Conflicts of Interest}

The authors declare no conflict of interests.

\section{References}

1. Wang, G.H. The Problem, Potential, Way and Benefit of China's Grain Production; Agricultural Press: Beijing, China, 1993.

2. Li, P.; Shao, J.A.; Zhang, Z.; Wei, C.F.; Qiu, D.C. Establishment of Balance of Cultivated Land in Chongqing. J. Nat. Resour. 2011, 26, 919-931.

3. Zhou, Y.; Luo, Y.Z. The Research about Balance of Cultivated Land Based on the Main-functional Zones in Chongqing. In Proceedings of the 2008 China Land Science Society Annual Meeting, Hefei, China, 21 November 2008.

4. Yan, H.M.; Liu, J.Y.; Huang, H.Q.; Tao, B.; Cao, M.K. Assessing the consequence of land use change on agricultural productivity in China. Glob. Planet. Chang. 2009, 67, 13-19.

5. Yan, H.M.; Liu, J.Y.; Huang, H.Q.; Dong, J.W.; Xu, X.L.; Wang, J.B. Impacts of cropland transformation on agricultural production under urbanization and grain for green project in China. Acta Geogr. Sin. 2012, 67, 579-588. 
6. Liu, J.Y.; Xu, X.L.; Zhuang, D.F.; Gao, Z.Q. The impact of LUCC process on potential productivity for crops of China in 1990s. Sci. China Ser. D 2005, 35, 483-492.

7. Xu, X.L.; Liu, J.Y.; Cao, M.K.; Zhang, S.W. Impact of recent climate fluctuation and LUCC process on potential productivity for crops in Northeast China. Sci. Geogr. Sin. 2007, 27, 318-324.

8. Weinhold, D. Estimating the loss of agricultural productivity in the Amazon. Ecol. Econ. 1999, 31, 63-76.

9. Ramankutty, N.; Foley, J.A.; Olejniczak, N.J. People on the land: Changes in global population and croplands during the 20th Century. AMBIO 2002, 31, 251-257.

10. Deng, X.Z.; Huang, J.K.; Rozelle, S.; Uchida, E. Cultivated land conversion and potential agricultural productivity in China. Land Use Policy 2006, 23, 372-384.

11. Yang, X.H.; Cheng, C.Z.; Li, Y.J. Effect of cropland occupation and supplement on light-temperature potential productivity in China from 2000 to 2008. Chin. Geogr. Sci. 2010, 20, 536-544.

12. Wang, J.; Yang, X.H.; Cai, H.Y.; Li, Y.-J. Spatio-temporal characteristics of light-temperature potential productivity on cropland occupation and supplement in China in the last 20 years. J. Nat. Resour. 2013, 28, 126-136.

13. Cai, H.Y.; Yang, X.H.; Xu, X.L. Spatiotemporal Patterns of Urban Encroachment on Cropland and Its Impacts on Potential Agricultural Productivity in China. Remote Sens. 2013, 5, 6443-6460.

14. Li, Y.J.; Yang, X.H.; Long, W.L. Topographic Dependence of Cropland Transformation in China during the First Decade of the 21st Century. Sci. World J. 2013, 2013, 303685:1-303685:12.

15. Liu, J.; Liu, M.; Zhuang, D.; Zhang, Z.; Deng, X. Study on spatial pattern of land-use change in China during 1995-2000. Sci. China Ser. D 2003, 46, 373-384.

16. Liu, J.; Liu, M.; Tian, H.; Zhuang, D.; Zhang, Z.; Zhang, W.; Tang, X.; Deng, X. Spatial and temporal patterns of China's cropland during 1990-2000: An analysis based on Landsat TM data. Remote Sens. Environ. 2005, 98, 442-456.

17. Liu, J.; Zhang, Z.; Xu, X.; Kuang, W.; Zhou, W.; Zhang, S.; Li, R.; Yan, C.; Yu, D.; Wu, S.; et al. Spatial patterns and driving forces of land use change in China during the early 21 st century. J. Geogr. Sci. 2010, 20, 483-494.

18. Zhou, W.C. Impact of Land Nature Slope and Sea Level Elevation on the Economic Development in the Three Gorges Area. Resour. Environ. Yangtza Basin 2001, 10, 15-21.

19. Wei, Y.Z.; Deng, N.R.; Wu, Z.F. Effects of Topography on Distribution and Change of Farmland in Mountainous Area of North Guangdong Province, China. J. Mt. Sci. 2008, 26, 76-83.

20. Luo, Y.Y.; Li, R.X.; Qu, M. Impact of Land Slope and Elevation on the Land Use Economy Development in Mountain Watersneld, Chongqing. J. Mt. Res. 2004, 22, 254-258.

21. Ma, Z.Z.; Zhou, A.X.; Jiang, X.B.; Zhou, W.C. Influences of Altitude and Slope on Dynamical Changes and Status Quo of Land Use/Cover in Wuhan County. J. Soil Water Conserv. 2003, 17, 107-109.

22. Fischer, G.; Shah, M.; Tubiello, F.N.; van Velhuizen, H. Socio-economic and climate change impacts on agriculture: An integrated assessment, 1990-2080. Philos. Trans. R. Soc. B Biol. Sci. 2005, 360, 2067-2083.

23. Fischer, G.; Tubiello, F.N.; van Velthuizen, H.; Wiberg, D.A. Climate change impacts on irrigation water requirements: Effects of mitigation, 1990-2080. Technol. Forecast. Soc. Chang. 2007, 74, 1083-1107. 
24. Tatsumi, K.; Yamashiki, Y.; Valmir da Silva, R.; Takara, K.; Matsuoka, Y.; Takahashi, K.; Maruyama, K.; Kawahara, N. Estimation of potential changes in cereals production under climate change scenarios. Hydrol. Processes 2011, 25, 2715-2725.

25. Li, X.J.; Qiao, J.J. Impact of landform on input-output of man-land system in farmland of mountainous region: A micro-study of a small village in Wugou of Henan Province. Geogr. Res. 2004, 23, 717-726.

(C) 2014 by the authors; licensee MDPI, Basel, Switzerland. This article is an open access article distributed under the terms and conditions of the Creative Commons Attribution license (http://creativecommons.org/licenses/by/4.0/). 